\title{
Hal Koch: Kirkehistoriker - demokrat - brobygger
}

\section{Opposition ved Tine Reehs forsvar af hendes disputats om Hal Koch}

\author{
Professor, dr.theol. \\ Jens Holger Schjørring
}

\begin{abstract}
On May 25, 2012 Tine Reeh defended her doctoral thesis at the University of Copenhagen on the Danish church historian, Hal Koch (1904-1963). Koch was an important figure in modern Danish history, not only as a theologian, but also as a pioneering innovator in adult education and nation-building during the Nazi occupation of Denmark. I start out paying tribute to Tine Reeh's accomplishments, not least for presenting a full-scale analysis of Hal Koch within the general framework of his time. At the same time some viewpoints in her account are questioned. Tine Reeh maintains that the German dialectical theology and its Danish parallel, Tidehverv, had a particular impact on Koch. She presents a detailed picture of Koch's monographs on Origen, on the relationship between church and state in medieval Denmark, and on Grundtvig, seen in interaction with Koch's position as Lutheran theologian and preacher. The analysis of Koch's activity during the years of German occupation has rightly been given particular attention. Yet, it is misleading to perceive 1945 as the year of conclusion. In the post-war period Koch presented several examples of a remarkable reorientation. Accordingly it is more appropriate to consider him a bridge-builder between church and society than to push him into the narrow confines of academic school theology.
\end{abstract}

Key words: Hal Koch - church history - adult education - nation-building - Luther - Grundtvig - anti-totalitarianism - democracy.

Den afhandling, der i dag forsvares for den teologiske doktorgrad, er en i hovedsagen vellykket analyse af en fascinerende og betydningsfuld skikkelse i dansk teologi og kirkeliv, kultur- og samfundsdebat i det 20. århundrede. ${ }^{1}$ Denne anerkendende karakteristik skal stå

1 Tine Reeh, Kristendom, historie, demokrati. Hal Koch 1932-1945. (København: Museum Tusculanums Forlag 2012), 722 s. Sidetalshenvisninger i det følgende er til denne afhandling, med mindre andet er anført. 
som oversætning for de mere kritiske bemærkninger, jeg i det følgende skal fremføre. For det er ifølge dansk disputatstradition sådan, at opponenterne ved forsvarshandlingen ikke skal anvende tiden på at fremstille afhandlingens fortjenester. Dette er allerede sket med indstillingen til det teologiske fakultetsråd. Derimod skal vi som opponenter stille kritisk-konstruktive spørgsmål med det overordnede formål at give impulser, så den faglige drøftelse kan blive ført videre, også efter dagen i dag. Når jeg i det følgende vil behandle en række problemstillinger, undertiden i form af kritiske spørgsmål, skal disse altså ses i dette perspektiv. Men for at undgå enhver misforståelse vil jeg kort referere nogle passager fra bedømmelsesudvalgets indstilling, hvori nogle af afhandlingens væsentligste fortjenester er anført:

Forfatteren har fremdraget, registreret og analyseret et særdeles omfattende materiale.

Forfatteren har tegnet et prægnant helhedsbillede af Hal Kochs store og komplekse forfatterskab i perioden frem til 1945 og påvist den nære forbindelse mellem Kochs publikationer og hans offentlige virke i den politiske idédebat og i opgøret om den aktuelle kultursituation og dens idehistoriske forudsætninger.

Tine Reeh har forstået at anskue hovedpersonen dels i hans individuelle egenart dels som katalysator for generelle tendenser og problemstillinger i perioden.

Forfatteren har gennemført en lødig drøftelse af den eksisterende faglitteratur om Hal Koch med skyldig inddragelse af den væsentligste litteratur om almene træk i samfunds- og kulturudviklingen samt de kirkelige og teologiske forhold.

På et afgørende sted giver Tine Reeh dog en uheldig karakteristik af den overordnede hensigt med afhandlingen. Som indledning til "Afsluttende bemærkninger" hedder det i forlængelse af et citat fra Koch selv: "Det er ikke denne afhandlings ærinde at afgøre, hvorvidt Hal Koch var en hero eller en kæltring. Det har derimod været et ønske at belyse, hvilke spørgsmål der drev ham og hans indsats, om der kan spores en kontinuitet i arbejdet, og hvori denne eventuelle kontinuitet bestod". Hero eller kæltring. Ét er, at dette citat fra Kochs side er situationsbestemt, en replik formuleret ind i den umiddelbare efterkrigssammenhæng, hvor der i forbindelse med retsopgøret og det almindelige opgør om de "fem onde år" var en tendens til at dele samfundet op i helte og skurke. Noget andet er, at det netop var Kochs overordnede ærinde som historiker at afvise tendenser til sorthvid kontrastering, sådan som det også flere gange af respondenten anføres, at Koch vendte sig imod tendenser til absolutering. Når det drejer sig om ærindet med den foreliggende afhandling, er der ingen tvivl om, at den er båret af en positiv optagethed af hovedpersonen og en fundamental sympati med hans hovedtanker. Det er der vel at 
mærke intet fordægtigt eller forkert ved, heller ikke i en disputats, når den blot holder sig til en analytisk, kritisk tilgang, sådan som det kendetegner denne disputats. Der er altså ikke tale om heroisering, men en legitim bestræbelse på at yde hovedpersonen retfærdighed og gøre personen og hans sag gældende for den opmærksomme nutidige læser.

I alt væsentligt er afhandlingen præget af klare formuleringer og omhu for detaljen, herunder nøjagtighed i gengivelsen af citater, også fra tysk, latin og andre fremmedsprog. Dog er der enkelte tidsler i buketten. Et eksempel: På side 549 hedder det følgende: "Koch betoner folkeskolen og bøndernes frigørelse som frugter af pietismen, men går ellers hastigt videre til det 19. århundrede, hvor Danmark på samme tid oplevede afgørende nederlag og tab i form af Norge, Holsten og Slesvig, men samtidig en lysende vækst indadtil”. Dette er et referat fra den lille, men væsentlige bog fra 1942, Dagen og Vejen. Men det er en ufuldstændig og misvisende gengivelse. I bogen taler Koch klart om pietismen og oplysningen/absolutismen. ${ }^{2}$ Når der er grund til at anholde denne tilsyneladende harmløse detalje har det følgende grunde:

For det første skal både citater og referater naturligvis være korrekte og dækkende. For det andet er det karakteristisk for Koch som historiker, at han netop ikke forfaldt til forsimplede, monokausale forklaringer, men altid, også i sine mange folkelige skrifter, søgte at fastholde en nuanceret synsvinkel, i dette tilfælde samspillet mellem de to forskellige, men hver for sig betydningsfulde fornyelser fra det 18. århundrede, pietismen og enevælden/oplysningstiden, der tilsammen udgjorde grundlaget for fremvæksten af dansk folkestyre i det 19. århundrede.

For det tredje er ordparret pietisme og oplysning en sammenstilling, der dukker op i flere sammenhænge hos Koch. Når det drejer sig om skoletanker og samfundsreformer, refererer det til væsentligt positive historiske forudsætninger for Grundtvig, jf. den før nævnte passage fra Dagen og Vejen, hvor det hedder om enevældens/oplysningstidens uvisnelige fortjeneste: "den skabte i Fællesskab med Pietismen og Kirkens Mænd den danske Folkeskole, og den gennemførte i Samarbejde med Adelens bedste Mænd Bøndernes Frigørelse" (Koch 1942, 33). Når det derimod drejer sig om Grundtvigs salmer, har pietisme og oplysning snarere negative konnotationer. F.eks. hedder det i Kochs bog om Grundtvig: "henover Oplysningstiden og Pietisme har han grebet tilbage til den gamle reformatoriske - til dels førreformatoriske

2 Hal Koch, Dagen og Vejen (København: Westermanns Forlag 1942), 33. 
- Salmedigtning". ${ }^{3}$ Men det er altså hele tiden pietisme sammen med enevælde og oplysning $i$ et differentieret samspil.

Gennemgående er sprogbrugen sober og præcis. Enkelte steder sker der et brud på stilen, idet der sniger sig en ubeskyttet, kæk betegnelse ind. Fx hedder det om Indre Missions Tidende i omtalen af striden mellem Christian Bartholdy og Hal Koch "det dengang forholdsvis indflydelsesrige Indre Missions Tidende” (357). Samme ilde medfart får Svensk Teologisk Kvartalskrift "det dengang toneangivende Svensk Teologisk Kvartalskrift" (129), og Theologische Literaturzeitung, hvorom det hedder: "det dengang indflydelsesrige Theologische Literaturzeitung" (127). Den form for karaktergivning er malplaceret og ganske unødvendig for den saglige karakteristik. Alle tre anførte tidsskrifter findes for øvrigt fortsat, men er måske nok ramt af den nedgang, der kendetegner næsten alle kirkelige og faglige tidsskrifter.

\section{Afhandlingens brug af kilder}

Afhandlingen er et digert værk, særdeles udførlig, også for udførlig. Navnlig en stor del af referaterne kunne med fordel have været strammet, $\mathrm{i}$ særdeleshed referaterne på anden hånd, f.eks. om andre Origenes-forskere eller andre Grundtvig-fortolkere. Men på et enkelt punkt er teksten ekstremt kortfattet, nemlig vedrørende metode og fremgangsmåde. Det hedder om kildesynet (18), at det er "såkaldt funktionelt", hvilket uddybes med følgende: "spørgsmål vedrørende Kochs teologiske og historiske interesse samt hans samfundsengagement er i første række søgt besvaret ud fra hans akademiske forfatterskab, hans prædikener samt hans henvendelser til offentligheden". Dette kunne med fordel have været uddybet, især for at klargøre forholdet mellem person og tænkning. To forhold forekommer mig væsentlige at kommentere: Det ene spørgsmål har at gøre med, at afhandlingen sætter ind med året 1932. Det betyder dog ikke, at alle aspekter, der vedrører tiden inden Kochs disputats, er udeladt. De er behandlet ind imellem i form af spredte indslag af flash back, hvor det er skønnet relevant. Alligevel trænger spørgsmålet sig på, om der ikke er akut fare for underbelysning af Kochs tidlige udvikling, når 1932 så programmatisk gøres til terminus a quo? Blandt de talrige sammenhænge, der går tilbage til årene inden 1932, nævner jeg blot følgende: betydningen af hjemmet, særligt forældrene; studietiden, såvel på Metropolitanskolen som på Det Teologiske Fakultet; årene som stipendiat med udenlandsrejser, indtrykkene fra teologi og kirke-

3 Hal Koch, Grundtvig (København: Gyldendal 1944), 199. 
liv i Danmark inden 1932, herunder Tidehvervs tidligste udvikling. Som sagt er disse sammenhænge ikke fraværende, men de forekommer underbelyst, og det angår det principielle forhold mellem person og tænkning.

Dette forhold forstærkes af endnu et åbent problem. Det hedder om brevene lakonisk: "Breve og manuskripter til foredrag indgår kun i det omfang, de kan udvide forståelsen". Det må man betegne som en ultrakort karakteristik, der giver forfatteren uindskrænket ret til selv at afgøre, hvor et brev evt. kunne udvide forståelsen, uden at læseren har nogen adgang til at få indseende med kriterierne. At brevene således er skudt i baggrunden bidrager derfor til yderligere at understrege det åbne spørgsmål om forholdet mellem person og tænkning. P.G. Lindhardt tilkendte i sin berømte bog Vakkelser og kirkelige retninger i Danmark fra 1950 netop breve særlig kildeværdi, til forskel fra f.eks. selvbiografier, fordi breve er førstehånds kilder, og de er skrevet uden tanke på offentliggørelse. Men i den foreliggende afhandling sporer man en bestræbelse på at holde det biografiske og personlige på afstand, hvilket kan være prisværdigt nok, for så vidt det drejer sig om at holde den nyfigne snagen ude og eftersom interessen - helt legitimt - først og fremmest gælder Hal Koch som teolog og historiker. Men alligevel vil det være berettiget at tillægge vekselvirkningen mellem person og tænkning større betydning, også angående årene inden 1932.

\section{Hal Koch og "den dialektiske teologi"}

I bestemmelsen af Kochs teologiske ståsted i tiden omkring 1932 lægger Tine Reeh med rette stor vægt på at inddrage en flerhed af teologiske inspirationskilder til disputatsen og de øvrige af Kochs tidlige arbejder. Men når det kommer til stykket, er der en bestemt teologisk tendens, der tillægges særlig betydning, nemlig det barthsk og tidehvervske, vel at mærke denne kombination mellem Karl Barth og Tidehverv, hvilket må være baggrunden for, at der flere gange tales i bestemt form og ental om "den dialektiske teologi". Men dette fører til en underbelysning af en række af betydningsfulde inspirationskilder for den tidlige Koch: Faderen Hans Koch, præst og kristeligsocial foregangsmand; den betydningsfulde franske oldkirkeforsker Eugène de Faye (som var en af grundene til, at Koch supplerede sin teologiske eksamen med en embedseksamen i fransk); den tyske patristiker Hans Lietzmann (Adolf von Harnacks efterfølger i Berlin) samt Jens Nørregaard, den professor ved fakultetet i København, der på dette tidspunkt betød mest som underviser og igangsætter for for- 
skertalenter; desuden altså Karl Barth og Tidehverv, selvom der over for både Barth og Tidehverv anføres flere forbehold, herunder vedrørende Tidehverv en forskel i synet på god debatkultur.

Det er en hovedsag i bogen at give et nuanceret billede af den dialektiske teologi som den afgørende teologiske fornyelse i mellemkrigsårene samt at karakterisere Tidehverv som en selvstændig dansk variant. Tine Reeh fremhæver ganske præcist det problematiske i at tale om dansk barthianisme som om der var tale om en entydig størrelse, når det dog var en disparat samling præster og teologer uden noget klart defineret fællesskab. Ligeledes omtales det flere gange, at Tidehverv ikke uden videre kunne stilles på linje med den dialektiske teologi i Tyskland, og at Koch tog væsentlige forbehold i forhold til såvel Karl Barth som Tidehverv. Men samtidig placeres Hal Koch teologisk hele tiden i samspil med den dialektiske teologi og Tidehverv. Det hedder således i de afsluttende bemærkninger, at Koch "var afgørende bestemt af Karl Barth og den tidlige dialektiske teologi" (686).

I forbindelse med disse synspunkter forekommer der at være behov for præciseringer. For det første: På det tidspunkt, hvor undersøgelsen sætter ind, 1932-1933, var det ikke længere dækkende at tale om den dialektiske teologi i ental. Den interne uenighed mellem de førende teologer omkring tidsskriftet Zwischen den Zeiten overskyggede den tidligere enighed. For det andet: Tidehvervs inspiration fra Barth i den indledende fase i tyverne blev i begyndelsen af trediverne afløst af en stadigt mere åbenbar distance. For det tredje: Hal Koch var ganske vist på vigtige punkter inspireret af Karl Barth og havde i udgangspunktet en vis sympati for Tidehverv, men han var dog fra begyndelsen uenig med Tidehverv om væsentlige spørgsmål.

Som det også flere steder omtales, kom Karl Barth til Danmark i marts 1933 og holdt forelæsninger i København og Aarhus. Allerede inden dette besøg var den tiltagende distance mellem Barth og Tidehverv trådt klart frem. Tidehverv forholdt sig ironisk til, at Barth netop i 1932 havde påbegyndt udgivelsen af sit monumentale hovedværk, Kirchliche Dogmatik. Det udgjorde for Tidehverv et knæfald for "kirkeligheden", noget nær det værste skældsord for den tidlige Tidehvervsbevægelse. Desuden gjorde Barth i de samme år programmatisk op med en luthersk teologi om de skabte ordninger, sådan som det bl.a. trådte frem hos hans kollega i arbejdsfællesskabet Zwischen den Zeiten, Friedrich Gogarten. Barth så i mange tyske lutheraneres knæfald for nazismen en understregning af, hvilke skæbnesvangre konsekvenser en bestemt tolkning af rækkefølgen lov-evangelium kunne få og rent faktisk fik i Tyskland i 1933. I stedet gik Barth nu programmatisk ind for den omvendte rækkefølge: evangeliumlov. Ud fra Tidehvervs synspunkt var Barth, den tidligere radikale oprører, i trediverne på vej til at indpasse sig efter det kirkelige og teo- 
logiske establishment, hvilket tidehvervsteologerne så tydeligt bevidnet, da kirkelige og teologiske honoratiores sad på første række under Barths forelæsning i København. Det kom alligevel til et møde, en privat sammenkomst, mellem Barth og repræsentanter for Tidehverv, et møde der endte som en eklatant fiasko. Tidehvervsteologerne så sig bestyrket i deres mistanke om, at Barth var gået på kompromis og var blevet kirkeligt tilpasset. Barth på sin side var utilpas ved de unge danske teologers umodne og uslebne polemiske stil.

Det er derfor næppe holdbart at tale om den dialektiske teologi i ental i 1932-33. Hvori bestod egentlig den i afhandlingen antydede overensstemmelse i udgangspunktet mellem Barth og Tidehverv? Og hvordan var forholdet mellem Kochs inspiration fra Barth og Tidehverv på den ene side og hans forbehold på den anden side?

\section{Hal Koch og Grundtvig}

Tolkningen af Grundtvig og analysen af Grundtvigs betydning for Kochs forfatterskab i det hele taget indtager helt berettiget en stor plads i afhandlingen. Der er et helt kapitel på 100 sider, der bærer overskriften "Arbejdet med Grundtvig". Men inddragelsen af Grundtvig er ikke begrænset til dette kapitel. Både tidligere og senere lægger Tine Reeh vægt på at inddrage Grundtvig i karakteristikken af Kochs teologiske standpunkt. Med et vist forbehold kan man sige, at det inden 1940 er således, at det er Grundtvigs kirkelige anskuelse, der træder tydeligst frem, mens det efter d. 9. april 1940 er således, at Grundtvigs folkelige tanker og deres relevans for mobiliseringen af den danske ungdom og for bevidstheden om det parlamentariske demokrati står i forgrunden. I perioden inden besættelsen er det som nævnt i højere grad Grundtvigs forståelse af gudstjenesten, konsekvenserne heraf for synet på forkyndelsen samt forholdet mellem det, der udgør menighedens grundvold, de guddommelige tiltaleord, sakramenterne og trosbekendelsen på den ene side og den videnskabelige teologis opgave på den anden. Men situationen under besættelsen gjorde det for Koch påkrævet at fokusere på Grundtvigs sans for, hvorfor den brede befolkning skulle myndiggøres som forudsætning for folkelig dannelse og dermed skabe et bæredygtigt grundlag for aktiv deltagelse i den politiske meningsdannelse og beslutningsproces.

I bogen Grundtvig, der er det skriftlige nedslag af de berømte forelæsninger fra efteråret 1940, synes de to aspekter at stå side om side, i smuk vekselvirkning med hinanden og uden tegn på, at den ene side skulle optage plads på den andens bekostning. Kapitel V har overskriften "Det historisk-kirkelige syn", kapitel X "Kirken”, mens 
kapitlerne VII- IX hedder hhv. "Det menneskelige og det folkelige", "Skolen” og "Menneske først og Kristen saa!”. På denne baggrund må man spørge, om der virkelig findes en sådan forskydning i accentueringen af Grundtvig hos Koch før og efter 1940? Og i bekræftende fald, hvordan påvirker det så afhandlingens hovedtese, at der for en overordnet betragtning er kontinuitet i Kochs forfatterskab?

\section{Hal Koch og Løgstrup}

Kochs virksomhed i besættelsesårene er formentlig den side af hans livsgerning, der er bedst kendt i forvejen: arbejdet i Dansk Ungdomssamvirke og i den forbindelse de mange, mange foredrag ud over hele landet, Grundtvig-forelæsningerne samt - ikke mindst - striden med K.E. Løgstrup. Alt dette er i elementær forstand godt stof. Det får i Tine Reehs undersøgelse en omhyggelig og nuanceret behandling, herunder også den lidenskabelige debat mellem Koch og Løgstrup. Tilbage står alligevel et par spørgsmål, som jeg gerne vil have respondenten til at uddybe:

Opgøret mellem Koch og Løgstrup var så voldsomt, at man i tilbageblik let kunne forfalde til udelukkende at se en afgrundsdyb uenighed mellem dem, først og fremmest i synet på hvad der var danskernes fundamentale pligt efter 9. april, den kompromisløse afvisning af regeringens samarbejdspolitik med heraf følgende argumentation for overgang til illegalitet (sådan som Løgstrup argumenterede for det), eller bestræbelsen på at kalde befolkningens sans for demokratiets værdier til live sammen med principiel argumentation for at støtte de valgte politikere (Kochs standpunkt).

Men det vil være en forenkling, hvis man kun ser gensidige anklager mellem to venner og kombattanter hen over en afgrundsdyb kløft. Forholdet mellem de to hovedpersoner efter 1945 beviser med al tydelighed, at der bag om den emotionelle stridssamtale var både gensidig sympati og også på vigtige punkter saglig enighed mellem dem, hvilket Tine Reeh også har blik for. Enigheden drejede sig både om deres syn på nazismen, deres faktiske vurdering af mange sider af samarbejdspolitikken, selvom Koch som sagt vedholdende forsvarede de valgte politikere, begges fremhævelse af, at der var livslove, som måtte respekteres, samt deres afvisning $\mathrm{i}$ enighed af en ligefrem kristelig materialetik. Men når nu hovedinteressen med afhandlingen er at analysere Kochs standpunkt som historisk teolog, hvori bestod så uenigheden på det principielle plan mellem de to, altså ikke kun deres konkrete holdning til samarbejdspolitikken, og på hvilke punkter var de enige? Det får læseren ikke tilstrækkelig meget at vide om 
I kapitlet om besættelsesårene søger Tine Reeh at lægge nogle nye brikker til den samlede mosaik, der gengiver Kochs hovedtanker, herunder hans syn på kristendom og politik samt hans inddragelse af en luthersk sondring mellem de to regimenter. I den forbindelse undrer det mig, at Tine Reeh ikke har inddraget den i mine øjne vigtigste danske udtalelse om netop kristendom og politik i den aktuelle situation under besættelsen, nemlig den af Regin Prenter udarbejdede erklæring om "Kirken og retten i den aktuelle situation", skrevet i foråret $1944 \mathrm{og}$ medundertegnet af K.E. Løgstrup. Den kunne ellers være et nok så konstruktivt indslag i undersøgelsen, bl.a. fordi Prenter var den danske teolog, der havde det nærmeste kendskab til Karl Barth, og fordi han samtidig var Luther-kender, på dette tidspunkt i 1944 umiddelbart foran forsvaret af sin disputats om Luthers forståelse af tredje trosartikel. Lad mig som yderligere begrundelse også anføre, at inddragelsen af "Kirken og retten" tillige kunne bidrage til perspektivering af det, der for Tine Reeh er hovedsagen i dette afsluttende kapitel, nemlig den konkluderende karakteristik af Koch som historisk teolog. Der gøres meget ud af at differentiere billedet og kigge tilbage på de tidligere kapitler. Den problemstilling, der i Kochs første afhandlinger var anliggendet, forholdet mellem kristendom og humanisme, bliver genstand for en fornyet analyse. Det bliver i denne forbindelse klart, at det ikke går an alene at tale om en rendyrket modstilling mellem kristendom og humanisme, men at der tillige må være tale om et "og", også mellem kirken og retten. Men dermed er vi tilbage ved problemstillingen om forholdet mellem en i den liberale tradition funderet kristelig humanisme på den ene side og en rendyrket dialektisk teologi på den anden. Jeg har allerede givet udtryk for, at jeg anser det for forfejlet, hvis man for ensidigt gør Koch til dialektisk teolog. Derimod kunne man sige, at han repræsenterer en tendens inden for nordisk lutherdom, der netop havde som sit særkende, at den gik uden om de ekstremer man så i tysk protestantisk teologi, herunder det skarpt optrukne alternativ mellem Karl Barth og den liberale teologi. Til denne nordiske lutherdom kunne man med føje henføre Koch, Løgstrup og Prenter, foruden Eivind Berggrav fra Norge og en række af lundenserteologerne fra Sverige, herunder Anders Nygren.

\section{Kontinuitet eller kursændringer?}

Det er en hovedtese $\mathrm{i}$ afhandlingen, at der er saglig kontinuitet $\mathrm{i}$ Kochs forfatterskab. Det betyder, at der ifølge Tine Reeh ikke kan observeres brud i henseende til Kochs standpunkt som historisk teo- 
$\log$, men at de nye tematiske arbejdsområder, der kom til efter 1932, snarere skal ses som tematiske supplementer til det standpunkt, der allerede var slået an med disputatsen. Denne tese om konsistens og kontinuitet i forfatterskabet er tillige Tine Reehs legitimation for at standse ved 1945. Det hævdes således, at der efter 1945 ikke sker noget afgørende nyt (685).

Denne argumentation kan jeg ikke uden videre følge. Ét er, at der er tale om en alt for massiv opdeling, hvis man kun regner med et alternativ mellem kontinuitet og brud. Dertil kommer, at der dog for mig at se virkelig er tale om en dynamisk videreførelse på ganske væsentlige områder i tiden efter 1945. Lad mig antyde dette med nogle observationer:

Kochs deltagelse i den offentlige debat i forbindelse med retsopg $\varnothing$ ret var i én forstand ganske vist en logisk forlængelse af hans virksomhed i besættelsesårene. Men i en anden forstand var der tale om en bemærkelsesværdig kursændring. De tidligere samarbejdspolitikere, som Koch så energisk havde forsvaret under krigen, viste sig nu for manges vedkommende at være opportunister og vendekåber. Koch blev derfor rasende og skånede dem ikke, da han deklamerede "Plager Fanden Jer", i øvrigt nu i fuld overensstemmelse med Løgstrups indlæg i samme sag. ${ }^{4}$

Opbygningen af Krogerup Højskole kan ligeledes ses som videreførelse af engagementet for Dansk Ungdomssamvirke. Men det er alligevel for pauvert, hvis man reducerer opbygningen af en folkehøjskole med et nyt koncept til at være noget, der bare lå i forlængelse af det tidligere engagement for ungdommens opdragelse til samfundsansvar.

Udarbejdelsen af bind VI af værket Den danske kirkes historie, omhandlende tiden 1800-1848, kan på tilsvarende vis ikke reduceres til at være et supplement til det, der allerede var skitseret i Grundtvig-bogen og de øvrige mindre afhandlinger om guldalderperioden. Ser man nærmere til, viser navnlig de indledende kapitler i den nye bog, der blev afsluttet i 1953, sig at være programmatiske oplæg til et kritisk revideret syn på samspillet mellem 18. og 19. århundrede. Det komplekse forhold mellem arven fra det 18. århundrede, samlet under betegnelserne pietisme, enevælde og oplysning, bliver nu udfoldet til en mere udarbejdet programerklæring om forholdet mellem guldalderperioden som på den ene side de store personligheders glansperiode, og på den anden side den begyndende omstrukturering af det danske samfund og de folkelige vækkelsesbevægelser.

Artikelsamlingen Et kirkeskifte. Studier over brydninger $i$ dansk kirke-og menighedsliv i 19. århundrede fra 1960 viser endnu en betyd-

4 Se fx K.E. Løgstrup, “Opgør eller Selvbedrag”. Tidehverv, sept.-okt. (1945), 67-82. 
ningsfuld udvidelse af Kochs virkefelt. Det beror dels på, at han her arbejdede sammen med en række yngre medarbejdere og dokumenterede sine evner som forskningsinspirator, dels at bogen i metodisk henseende åbenbarede en ny ansats, for så vidt den slog til lyd for en programmatisk indarbejdelse af vekselvirkningen mellem samfundsforandringer og kirkeliv i 19. århundrede. Man kan også sige, at bogen indirekte var affødt af Kochs klare fornemmelse for den fundamentale forandringsproces, der i efterkrigsperioden gik igennem hele det danske samfund, den endelige overgang fra et bondesamfund med tyngdepunkt i landsbyerne til et industrisamfund med tyngdepunkt i hovedstaden og de større provinsbyer. Denne udvikling ville Koch anskue i et større historisk perspektiv. På dette grundlag kan man derfor hævde, at der med denne bog bliver lagt et nyt materiale frem til anskueliggørelse af det betydningsfulde problem, som Tine Reeh flere gange i sin bog berører, nemlig den vanskelige men også væsentlige balancekunst mellem at være historisk teolog og dermed respektere historien som fortid og samtidig være en opmærksom og engageret analytiker, der skriver historie, så den har noget at sige for en nutidig læser.

Endelig må Kochs sidste publikation, det lille men væsentlige hefte, Fremtiden formes. U-landshjalp og Ydre Mission fra 1962 ikke overses. Det viser en kirkehistoriker, der i globalt perspektiv fornemmer den epokale rækkevidde af afkoloniseringsprocessen og fremvæksten af nye kirkesamfund i de nye stater. Heftet viser i særdeleshed Kochs sans for den fundamentale vanskelighed, der har fulgt os gennem de forløbne 50 år, forholdet mellem statslig udviklingsbistand og hjælpearbejdet gennem de kirkelige missionsorganisationer. Det viser frem for alt en kirkehistoriker, der mod slutningen af sit liv blev klar over, at det ikke gik an at begrænse kirkehistorien til at omhandle kirkerne i Europa, men erkendte, at det var en uomgængelig forpligtelse at se på kristendommens globale udbredelse.

Der kan derfor i mine øjne ikke være tvivl om, at Kochs udvikling fra 1945 til 1963 må betegnes som en dynamisk videreførelse med kursjusteringer og tilførsel af nye aspekter, uden at man af den grund kan anfægte Tine Reehs indledende tese, hvor det hedder, at der "tegner sig et billede af en sammenhængende, intellektuel virksomhed, der er samlet om en problemkreds vedrørende kristendom og kultur, kirke og stat samt eksistens og fællesskab” (16). 


\section{Hal Koch som brobygger}

Som afslutning ønsker jeg at gøre nogle bemærkninger om Tine Reehs konkluderende karakteristik af Hal Koch som historisk teolog. Som det vil være fremgået gør Tine Reeh sig umage for at nuancere. Når det kommer til stykket, indplaceres Kochs standpunkt i krydsfeltet mellem den liberale tradition og den dialektiske teologi, den liberale tradition med dens betoning af den ret forståede vekselvirkning mellem kristendom og humanisme og dens betoning af netop den historiske teologi, over for den dialektiske teologi med dens accentuering af afstanden mellem evangelium og humanisme og dens opgør med alle former for etisk idealisme. I dette krydsfelt hos Koch tillægger Tine Reeh endvidere arbejdet med Luther og Grundtvig formende betydning.

Uden på nogen måde at afvise enhver berettigelse af denne karakteristik - for den har meget for sig -, vil jeg dog foreslå et andet udgangspunkt for en samlet karakteristik af Hal Koch. Han var brobygger. I flere væsentlige henseender vel at mærke. Lad mig prøve at skitsere nogle aspekter, der falder mest i øjnene:

Koch var brobygger mellem teologi og kirke.

Han etablerede samtale mellem fagteologien og det folkelige Danmark.

Han søgte at skabe konstruktiv dialog mellem udforskningen af kristendommens tusindeårige historiske udvikling og debatten om den nutidige virkelighed i kirke og samfund.

Han etablerede en vekselvirkning mellem dansk kirkelig og kulturel tradition og europæisk civilisationshistorie og dannelsestradition.

Han arbejdede vedholdende på at fastholde og udbygge dialogen mellem teologien og de øvrige videnskaber.

Han gjorde det til en hovedsag at skabe aktivt samvirke mellem det akademiske studium af Grundtvig og de grundtvigske miljøer i kirke, skole og politik.

Han var en integrativ personlighed, der nok havde en skarp replik, men samtidig havde en sjælden evne til at etablere personlige og faglige kontakter og fastholde dem, selv når der faldt knubbede ord.

Om jeg ser ret, er en opmærksomhed omkring Koch som brobygger på ingen måde ensbetydende med at gøre ham til en farveløs kompromismager, ligeså lidt som det indebærer at han dermed skulle friholdes for kritiske synsvinkler på hans tanker og virke. Men det fastholder åbenheden $\mathrm{i}$ hans standpunkt og kan dermed bidrage til at gøre ham vedkommende også for nutidige læsere. 